\title{
Mucosal Melanoma of the Head and Neck pT4b TNM Finding v7
}

National Cancer Institute

\section{Source}

National Cancer Institute. Mucosal Melanoma of the Head and Neck pT 4b TNM Finding v7. NCI Thesaurus. Code C89134.

Mucosal melanoma of the head and neck with very advanced disease. T umor involves brain, dura, skull base, lower cranial nerves (IX, X, XI, XII), masticator space, carotid artery, prevertebral space, or mediastinal structures. (from AJCC 7th Ed.) 